\title{
Functional Synaptic Projections onto Subplate Neurons in Neonatal Rat Somatosensory Cortex
}

\author{
Ileana L. Hanganu, ${ }^{1}$ Werner Kilb, ${ }^{1}$ and Heiko J. Luhmannn ${ }^{1,2}$ \\ 1/nstitute of Neurophysiology, Heinrich-Heine-University Düsseldorf, D-40001 Düsseldorf, Germany, and 2Institute of \\ Physiology and Pathophysiology, Johannes Gutenberg University Mainz, D-55099 Mainz, Germany
}

\begin{abstract}
Subplate neurons (SPn) play an important role in the formation of thalamocortical connections during early development and show glutamatergic and GABAergic spontaneous synaptic activity. We characterized these synaptic inputs by performing whole-cell recordings from SPn in somatosensory cortical slices of postnatal day $0-3$ rats. At $-70 \mathrm{mV}$, electrical stimulation of the thalamocortical afferents elicited in $68 \%$ of the SPn a monosynaptic CNQX-sensitive postsynaptic current (PSC). These fast PSCs were mediated by AMPA receptors, because they were prolonged by cyclothiazide and blocked by GYKI 52466. On membrane depolarization, thalamocortical stimulation elicited in $50 \%$ of the cells an additional slow monosynaptic component mediated by NMDA receptors. Stimulation of the cortical plate evoked in $72 \%$ of SPn a monosynaptic AMPA receptor-mediated PSC with an additional NMDA component at depolarized membrane potentials and in $40 \%$ of the investigated cells polysynaptic responses, depending on $\mathrm{GABA}_{\mathrm{A}}$ and NMDA
\end{abstract}

The mechanisms by which the thalamocortical connections in the developing cortex become topographically ordered are not completely understood. During the initial, fetal developmental stage, ingrowing thalamic axons are guided to their appropriate cortical targets by molecular cues intrinsic to the cortex (for review, see Rakic, 1988; Bolz and Castellani, 1997; Levitt et al., 1997). In the second, perinatal phase, the thalamocortical innervation may be refined in an activity-dependent manner (for review, see Katz and Shatz, 1996; Feller, 1999; Zhang and Poo, 2001). An important function for this refinement process is attributed to early generated neurons forming the subplate (Catalano and Shatz, 1998). Subplate neurons (SPn), a heterogeneous population of cells located directly under the cortical plate (Kostovic and Rakic, 1980; Wahle and Meyer, 1987; Valverde et al., 1989), are actively involved in the pathfinding of corticopetal and corticofugal axonal projections. During early development, thalamocortical axons grow toward the cortex and form temporary synapses on SPn (Rakic, 1977; Catalano and Shatz, 1998). Whether these axons "wait" in the subplate (Rakic, 1977; Ghosh and Shatz, 1992a) or directly grow to their final targets in layer IV (Kageyama and Robertson, 1993) remains controversial. However, deletion of the

\footnotetext{
Received Feb. 20, 2002; revised May 14, 2002; accepted May 20, 2002.

This work was supported by Deutsche Forschungsgemeinschaft Grant Lu 375/3 and Neuroscience Graduate Program GRK 320. We thank B. Hellmuth for excellent technical assistance, Dr. J. Staiger for competent help in morphological cell classification, and Dr. I. Világi for kindly providing GYKI 52466.

Correspondence should be addressed to Heiko J. Luhmann, Institute of Physiology and Pathophysiology, University of Mainz, Saarstrasse 21, D-55099 Mainz, Germany. E-mail: luhmann@uni-mainz.de.

Copyright (C) 2002 Society for Neuroscience $0270-6474 / 02 / 227165-12 \$ 15.00 / 0$
}

receptors. Stimulation of the subplate elicited in $67 \%$ of SPn a monosynaptic dual-component PSC mediated by AMPA and NMDA receptors activated at $-70 \mathrm{mV}$ and in $12 \%$ of SPn a monosynaptic single-component PSC mediated by AMPA receptors with an additional NMDA component activated at depolarized membrane potentials. A monosynaptic GABAergic response could be observed in $68 \%$ of SPn after stimulation of the subplate. In gramicidin-perforated patch recordings, bath application of GABA caused membrane depolarization to $-40 \mathrm{mV}$ and elicited action potentials. These results demonstrate that SPn receive distinct functional synaptic inputs arising from the thalamus, cortical plate, and subplate, indicating that SPn are capable of integrating and processing information from cortical and subcortical regions.

Key words: subplate neurons; development; evoked postsynaptic currents; somatosensory cortex; glutamatergic and GABAergic receptors; synaptic circuit. subplate (Ghosh and Shatz, 1992b) or its improper differentiation (Zhou et al., 1999) causes an inappropriate thalamocortical innervation and prevents the accurate formation of layer IV. These data indicate that molecular markers as well as electrical activity patterns in the subplate may influence the ingrowing thalamocortical axons.

SPn express NMDA receptors, AMPA/kainate receptors (Herrmann, 1996; Smith and Thompson, 1999), and GABA receptors (Huntley et al., 1990; Meinecke and Rakic, 1992), which may be involved in glutamatergic and GABAergic synaptic transmission. Furthermore, SPn exhibit symmetrical as well as asymmetrical synapses with mature structural properties (Chun and Shatz, 1988; Herrmann et al., 1994), suggesting that they receive inhibitory and excitatory synaptic inputs. Electrophysiological evidence for functional synaptic inputs onto SPn has been provided by Friauf et al. (1990) and Friauf and Shatz (1991), and using whole-cell recordings from visually identified SPn, we have previously identified spontaneous synaptic inputs mediated by AMPA, NMDA, and $\mathrm{GABA}_{\mathrm{A}}$ receptors (Hanganu et al., 2001). These data indicate that SPn are integrated in a synaptic circuit, which is transiently expressed in the developing cortex.

We performed whole-cell recordings from visually identified and biocytin-labeled SPn in neonatal rat cortical slices to study the functional properties of stimulus-evoked synaptic inputs arising from the thalamus, the cortical plate, including layers $\mathrm{V}$ and VI, and the subplate. Our data indicate that SPn receive an AMPA and NMDA receptor-mediated input from all three structures and a GABAergic input from other SPn, supporting the hypothesis that the subplate may function as a transient relay 
station integrating subcortical and cortical inputs during early development. We also performed gramicidin-perforated patch recordings to address the question of whether GABA application has a hyperpolarizing or depolarizing effect on SPn in newborn rat cortex.

\section{MATERIALS AND METHODS}

Slice preparation and electrophysiological recordings. All experiments were conducted in accordance with the national laws for the use of animals in research and approved by the local ethical committee. The preparation of brain slices and the whole-cell patch-clamp recording techniques were similar to those described previously (Hanganu et al., 2001). Briefly, 0- to 3-d-old male Wistar rats were anesthetized by hypothermia and decapitated. Whole-brain coronal slices (400 $\mu \mathrm{m}$ thick) including the primary somatosensory cortex were cut on a vibroslicer (TPI, St. Louis, MO) and divided into two hemispheres. Slices were maintained $>1 \mathrm{hr}$ at $33^{\circ} \mathrm{C}$ in a storage chamber before transferring them into submerged recording chamber. During preparation and recording procedures, the slices were maintained in artificial CSF (ACSF) containing (in $\mathrm{mM}$ ): $124 \mathrm{NaCl}, 26$ $\mathrm{NaHCO}_{3}, 3 \mathrm{KCl}, 1.6 \mathrm{CaCl}_{2}, 1.8 \mathrm{MgCl}_{2}, 1.3 \mathrm{NaH}_{2} \mathrm{PO}_{4}$, and 20 D-glucose, $\mathrm{pH} 7.4$, after equilibration with $95 \% \mathrm{O}_{2}$ and $5 \% \mathrm{CO}_{2}$ (osmolarity, 333 mOsm).

Whole-cell and perforated patch recordings were obtained from SPn visualized with video-enhanced infrared Nomarski optics in a recording chamber mounted on the fixed stage of an Axioskop microscope (Zeiss, Oberkochen, Germany). All recordings were performed at $32-33^{\circ} \mathrm{C}$. Recording electrodes (8-15 $\mathrm{M} \Omega$ ) were filled with standard electrode solution containing (in mM): $117 \mathrm{~K}$-gluconate, $13 \mathrm{KCl}, 1 \mathrm{CaCl}_{2}, 2 \mathrm{MgCl}_{2}$, 11 EGTA, 10 K-HEPES, 2 NaATP, and 0.5 NaGTP. For determination of the current-voltage relationship of postsynaptic currents (PSCs), 10 mM lidocaine $N$-ethyl bromide (QX-314) was added to the electrode solution to block voltage-dependent sodium channels. For the investigation of $\mathrm{GABA}_{\mathrm{A}}$ receptor-mediated synaptic currents, K-gluconate was replaced by $117 \mathrm{~mm} \mathrm{KCl}$. For perforated patch recordings, gramicidin (dissolved in DMSO) as a perforation agent was added in a final concentration of $1 \mu \mathrm{g} / \mathrm{ml}$ to an electrode solution containing (in $\mathrm{mM}$ ): 126 K-gluconate, $4 \mathrm{KCl}, 1 \mathrm{CaCl}_{2}, 2 \mathrm{MgCl}_{2}, 11 \mathrm{EGTA}$, and $10 \mathrm{~K}$-HEPES. The electrode solutions were adjusted to $\mathrm{pH} 7.4$ with $1 \mathrm{M} \mathrm{KOH}$ and to an osmolarity of $306 \mathrm{mOsm}$ with sucrose.

Capacitance artifacts and series resistance were minimized using the built-in circuitry of the patch-clamp amplifier (EPC9; Heka, Lambrecht, Germany, for whole-cell recordings; and SEC05L; NPI, Tamm, Germany, for perforated patch recordings). The signals were low-passfiltered at $2.9-3 \mathrm{kHz}$, recorded online, and analyzed with WinTida Software (Heka). For perforated patch recordings, the progress of perforation was evaluated by monitoring the capacitative current transient to a $10 \mathrm{mV}$ step in holding potential. Series resistances $<35 \mathrm{M} \Omega$ obtained after 5-30 min represented the premise for starting the recordings. All potentials were corrected for liquid junction potentials with $-10 \mathrm{mV}$ for the gluconate-based electrode solution (Mienville and Pesold, 1999) and $-4 \mathrm{mV}$ for the high-chloride electrode solution (Marty and Neher, 1995). The resting membrane potential (RMP) was measured immediately after obtaining the whole-cell configuration. For the determination of the input resistance $\left(R_{\mathrm{in}}\right)$, hyperpolarizing current pulses of $2 \mathrm{sec}$ duration were applied from a holding potential of $-70 \mathrm{mV}$.

Histology and morphological analyses. In all experiments, $0.5 \%$ biocytin (Sigma, Deisenhofen, Germany) was included in the patch electrode solution for later morphological cell identification. Intracellular diff usion of biocytin from the electrode followed by active transport resulted in adequate filling of the recorded neurons (Figs. 1C, 2). The staining protocol for biocytin was described previously (Schröder and Luhmann, 1997). For combined biocytin and Nissl staining, osmium tetroxide was omitted from the reaction. Biocytin-stained neurons were analyzed in their somatodendritic properties using an Axioskop microscope (Zeiss) equipped with a drawing tube, and camera lucida reconstructions were made at $250 \times$ magnification. An Axiophot II microscope (Zeiss) equipped with a motorized $\mathrm{Z}$ stage was used to take digital photographs (Fig. 2) as Z stacks with a CoolSNAP CCD camera (Visitron Systems, Puchheim, Germany). Such stacks were processed with MetaView 4.5 (Universal Imaging Corp., West Chester, PA) using the minimum projection to achieve an "extended focus view."

Pharmacological procedures. All substances were purchased from Merck (Darmstadt, Germany) with the exception of CNQX and QX-314, which were from Tocris (Ballwin, MO), GABA and $\alpha$-(4-hydroxy- phenyl)- $\beta$-(4-benzylpiperidin-1-yl)- $\beta$-methylethanoltartrate (ifenprodil), which were from Sigma, and ( \pm )- or $R(-)-3$-(2-carboxypiperazin-4-yl)propyl-1-phosphonic acid (CPP), 2-(3-carboxypropyl)-3-amino-6-(4methoxyphenyl) pyridazinium bromide (gabazine), cyclothiazide (CYZ), and tetrodotoxin citrate (TTX), which were from Research Biochemicals (Natick, MA). 1-(4-Aminophenyl)-4-methyl-7,8-methylenedioxy-5H-2,3benzodiazepine (GYKI 52466) was kindly provided by Dr. I. Világi (Eötvös Loránd University, Budapest, Hungary). Stock solutions of these drugs were prepared as follows: TTX, CPP, GABA, and ifenprodil in distilled water; CNQX, gabazine, and CYZ in DMSO; and GYKI 52466 in HCl. Stock solutions were stored at $-20^{\circ} \mathrm{C}$ and diluted in ACSF on the day of the experiment. QX-314 was dissolved directly in the electrode solution on the day of the experiment. The maximal concentration of DMSO in the superfusate was $0.1 \%$. The drugs were bath-applied after stable control recordings were obtained for at least $6 \mathrm{~min}$ and reached a synaptic location within the first 5 min of application. During perforated patch recordings, GABA was bath-applied for 10-30 sec. Generally, a drugfree ACSF wash was applied before and after each drug application. A partial or complete washout was obtained after 5-45 min. During an experiment, the series resistance was continuously controlled. Typical recordings lasted 30-60 min, and up to four drugs were tested on the same cell.

Extracellular stimulation. A bipolar tungsten electrode (5 M $\Omega$; FHC, Bowdoinham, ME) was used for electrical stimulation of the thalamocortical afferents (TAs) and the cortical plate (CP), including layers V and VI and the subplate (SP), whereas the stimulus-evoked PSCs were recorded in SPn. The positions of the extracellular electrode in cortical and subcortical regions are indicated schematically in Figure $1 A$. For a precise stimulation of the TA, we determined in 10 slices the path of the thalamocortical projection by injecting a biocytin crystal into the cortex (for details, see Staiger et al., 1999). In accordance with previous anatomical studies (Shatz and Luskin, 1986; Molnár et al., 1998), these extracellular biocytin injections in newborn rat cortical slices revealed the characteristic path of thalamocortical axons (Fig. 1B). For electrical stimulation of the TA, a bipolar tungsten electrode (tip separation, $600-800 \mu \mathrm{m}$ ) was positioned in the internal capsule $\sim 500 \mu \mathrm{m}$ laterally to the recorded cell (Fig. $1 A, B$ ). The deeper CP layers including layers $\mathrm{V}$ and VI or the subplate were stimulated with a bipolar tungsten electrode with a tip separation of $150-200 \mu \mathrm{m}$, and a horizontal cut was performed directly below the white matter to eliminate possible inputs from subcortical regions. Because the connections between the $\mathrm{CP}$ and the subplate are organized radially (Antonini and Shatz, 1990), the CP stimulation electrode was positioned in the same vertical axis as the recorded cell. For electrical stimulation of the subplate, the stimulation electrode was placed $\sim 200 \mu \mathrm{m}$ laterally to the investigated SPn. In all experiments, the duration of the electrical stimulus was $70 \mu \mathrm{sec}$. The intensity of the stimuli varied between 20 and $85 \mathrm{~V}$ for stimulation of TA and between 0.5 and $85 \mathrm{~V}$ for stimulation of the $\mathrm{CP}$ and subplate. Unless otherwise noted, stimuli were delivered at $0.033 \mathrm{~Hz}$. Four to 10 stimulus-evoked responses were recorded under control conditions and after drug application to ensure the action of antagonists. The PSCs were analyzed with WinTida software (Heka) in their peak amplitude, onset latency, rise time, and decay time constant. The latency was measured from the beginning of the stimulus artifact to the onset of the PSC. Rise time was determined as the interval between baseline and peak current amplitude, and the decay time constant $(\tau)$ was calculated by fitting a single or double exponential function to averaged PSCs using a simplex algorithm. Correlation coefficients were calculated using a least squares linear regression analysis. Voltage steps of $20 \mathrm{mV}$ between -90 and $+30 \mathrm{mV}$ were applied to determine the current-voltage relationship of the synaptic inputs.

Data are presented as mean \pm SEM. For statistical analyses, the two-tailed Student's $t$ test, one-way ANOVA test, and $\chi^{2}$ test were used. Significance levels of $p<0.05, p<0.01$, and $p<0.001$ were considered.

\section{RESULTS}

Whole-cell recordings were performed from 306 SPn in somatosensory cortical slices from postnatal day 0 (P0) to P3 rats. The subplate was identified under video-assisted Nomarski microscopy and in Nissl-stained sections (Fig. 1C) as a layer characterized by a relatively low cell density and by the presence of horizontally oriented neurons (Bayer and Altman, 1990). In contrast, the $\mathrm{CP}$ and layers $\mathrm{V}$ and VI above the subplate show a high 

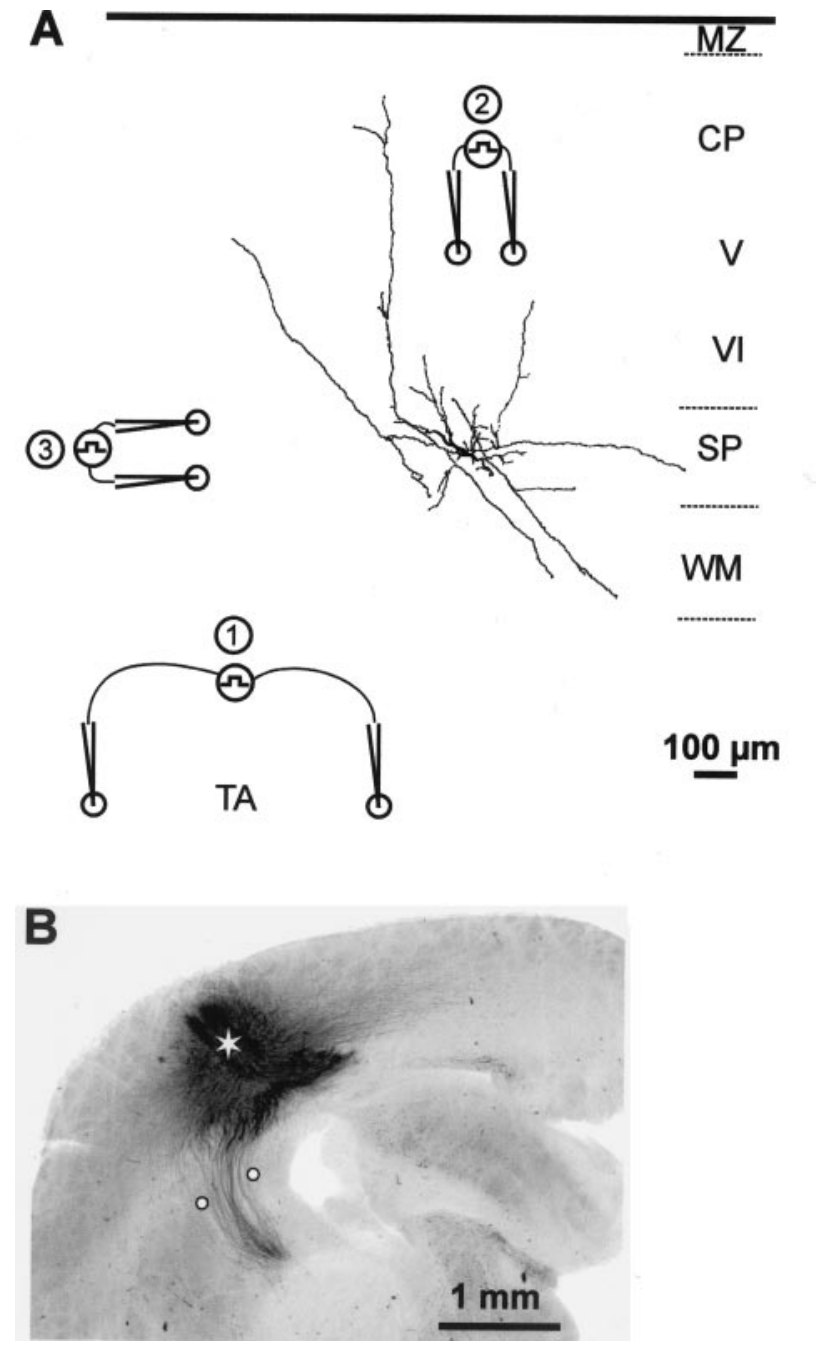

cell density and radially oriented neurons. The cell-sparse white matter marks the lower border of the subplate. The appearance of SPn under video-assisted Nomarski microscopy (Hanganu et al., 2001, their Fig. $1 A$ ), their characteristic firing pattern (Friauf et al., 1990; Luhmann et al., 2000; Hanganu et al., 2001), and their morphological properties after histological processing for biocytin (Fig. 2) served as additional criteria to identify the SPn.

\section{Morphological properties of SPn}

The exact morphology of 178 SPn was analyzed in more detail (Fig. 2). According to previously described morphological criteria (i.e., the form of the soma and the orientation of the dendritic tree; Wahle et al., 1987, 1994; DeAzevedo et al., 1997), six types of SPn were characterized. Horizontal bitufted (Fig. 2A) $(n=53)$ and monotufted (Fig. $2 B)(n=18)$ SPn showed a spindle-like, horizontally orientated soma with primary dendrites extending parallel to the pial surface in opposite directions or in only one direction. Neurons with a round or ovoid soma and multiple primary dendrites with no preferential orientation were classified as multipolar SPn (Fig. $2 C)(n=48)$. Inverted pyramid SPn (Fig. $2 D)(n=31)$ showed a triangular or round soma with a major dendrite oriented toward the white matter. Tripolar (pyramidlike) SPn (Fig. 2E) $(n=25)$ had a triangular or round soma and a major dendrite oriented to the pial surface. Three SPn showed a vertically oriented soma and radial dendrites and were classified as vertical SPn. Because we could not detect any statistically

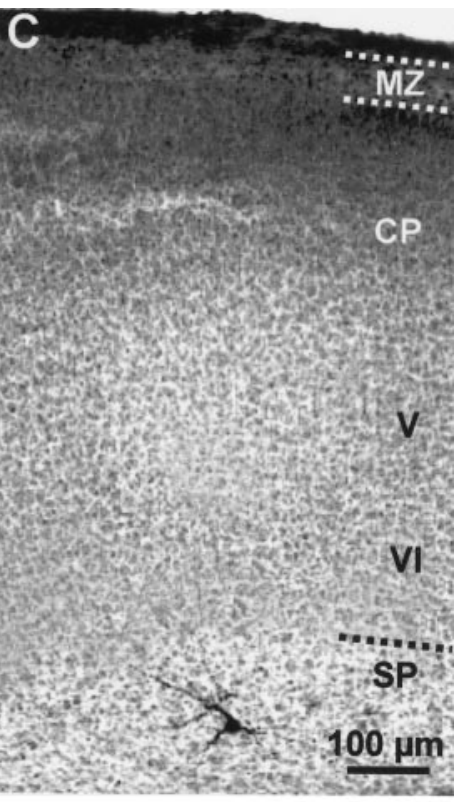

Figure 1. A, Morphology of a P2 SPn reconstructed with a camera lucida and schematic illustration showing the location of the bipolar tungsten electrode used for electrical stimulation of the TA (1), CP and layers V and VI (2) and the SP (3). Note the larger interpole distance of electrode 1 compared with electrodes 2 and 3. B, Photomicrograph of biocytin-stained thalamocortical projections in a $400-\mu \mathrm{m}$-thick coronal slice from a P1 rat. The asterisk shows the extracellular injection site of the biocytin crystal, and white circles mark the positions of TA-stimulating electrodes. $C$, Photomicrograph of a Nissl-stained coronal section with biocytin-labeled SPn in a P2 rat. Note densely cell-packed CP and layers V and VI compared with the cellsparse SP. $M Z$, Marginal zone; $W M$, white matter. significant difference between these six types of SPn in their electrophysiological properties (one-way ANOVA test) or synaptic inputs $\left(\chi^{2}\right.$ test $)$, data from these morphologically distinct SPn were pooled.

\section{Membrane properties of SPn}

The passive membrane properties and firing patterns were similar to those reported previously (Friauf et al., 1990; Luhmann et al., 2000; Hanganu et al., 2001). Using a gluconate-based electrode solution, the average RMP and $R_{\text {in }}$ were $-55.3 \pm 0.4 \mathrm{mV}$ and $1342 \pm 37 \mathrm{M} \Omega(n=184)$, respectively. Similar values were obtained using a chloride-based electrode solution (RMP, $\left.-54.1 \pm 0.7 \mathrm{mV} ; R_{\mathrm{in}}, 1232 \pm 76 \mathrm{M} \Omega ; n=53\right)$. All SPn were able to fire one or repetitive overshooting action potentials in response to sustained depolarization by intracellular current injection.

\section{PSCs evoked by stimulation of the TA}

PSCs in response to electrical stimulation of the TA (TA-PSCs) could be obtained in $68 \%$ of the 59 investigated SPn (Fig. $3 A$ ) and were completely abolished by bath application of $1 \mu \mathrm{M}$ TTX $(n=$ 8 cells). The short onset latency $(5.7 \pm 0.3 \mathrm{msec} ; n=40$ cells $)$ and the unimodal distribution of the latencies (Fig. $3 A$, inset) argue for the monosynaptic character of the TA-PSCs. The amplitudes of the TA-PSCs varied considerably among the cells, ranging from 12 to $79 \mathrm{pA}(29.7 \pm 2.7 \mathrm{pA} ; n=40$ cells $)$. The TA-PSCs had a rise time of $2.5 \pm 0.1 \mathrm{msec}(n=40$ cells $)$, and their decay could 

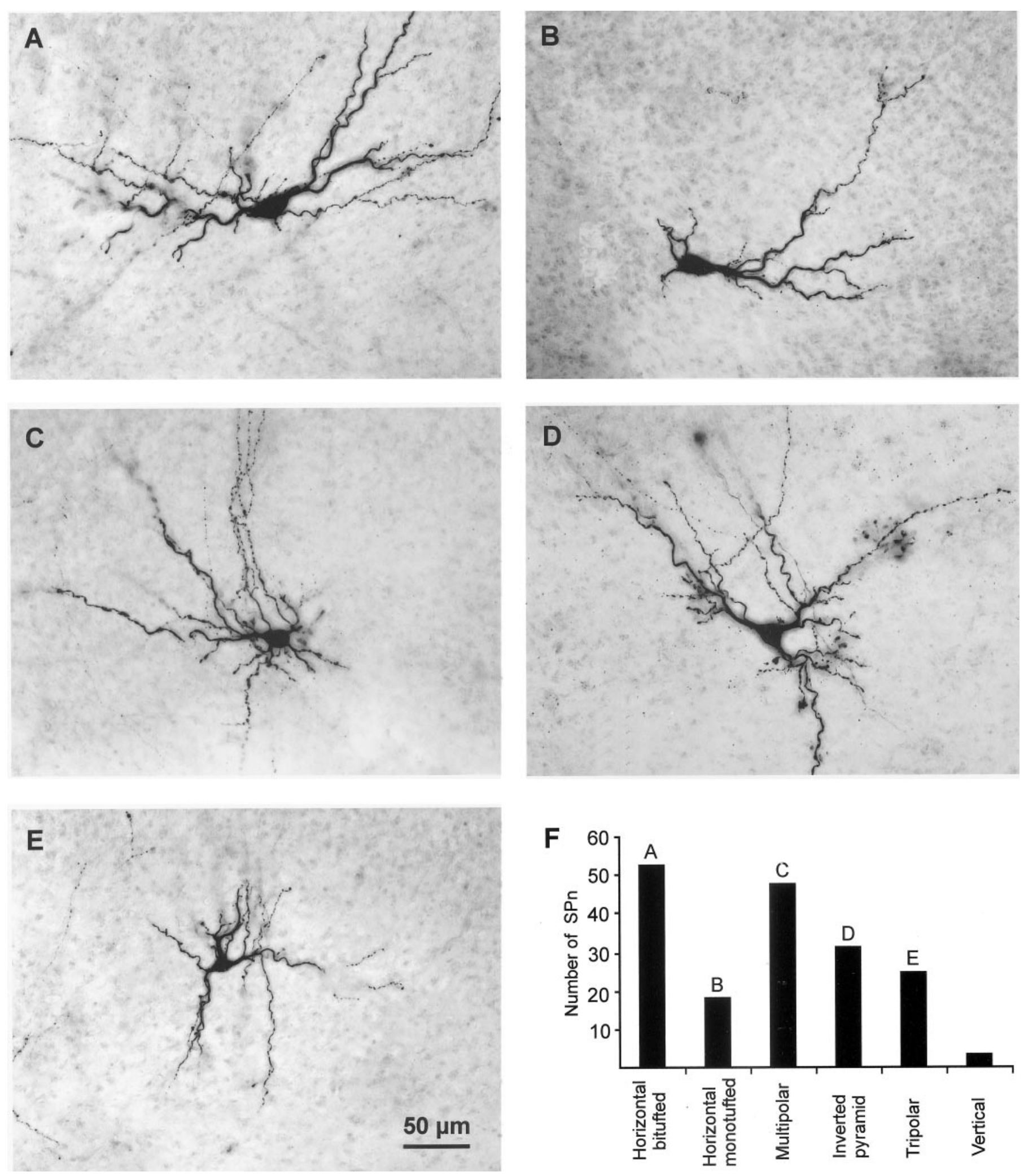

Figure 2. Morphological classification of biocytin-stained SPn in newborn rat cortex. $A, \mathrm{P} 3$ horizontal bitufted cell with a large fusiform soma and primary dendrites oriented parallel to the pial surface. $B, \mathrm{P} 2$ horizontal monotufted SPn. $C, \mathrm{P} 3$ multipolar cell with extensive dendritic arborization within the SP and layers V and VI. D, P2 inverted pyramidal neuron with a triangular soma and "apical" dendrite oriented toward white matter. $E$, P3 tripolar SPn. Scale bar in $E$ corresponds to $A-E$; pial surface is located toward the top. $F$, Bar diagram illustrating number of biocytin-stained SPn in the six morphological cell classes. Letters refer to the corresponding photomicrograph. 

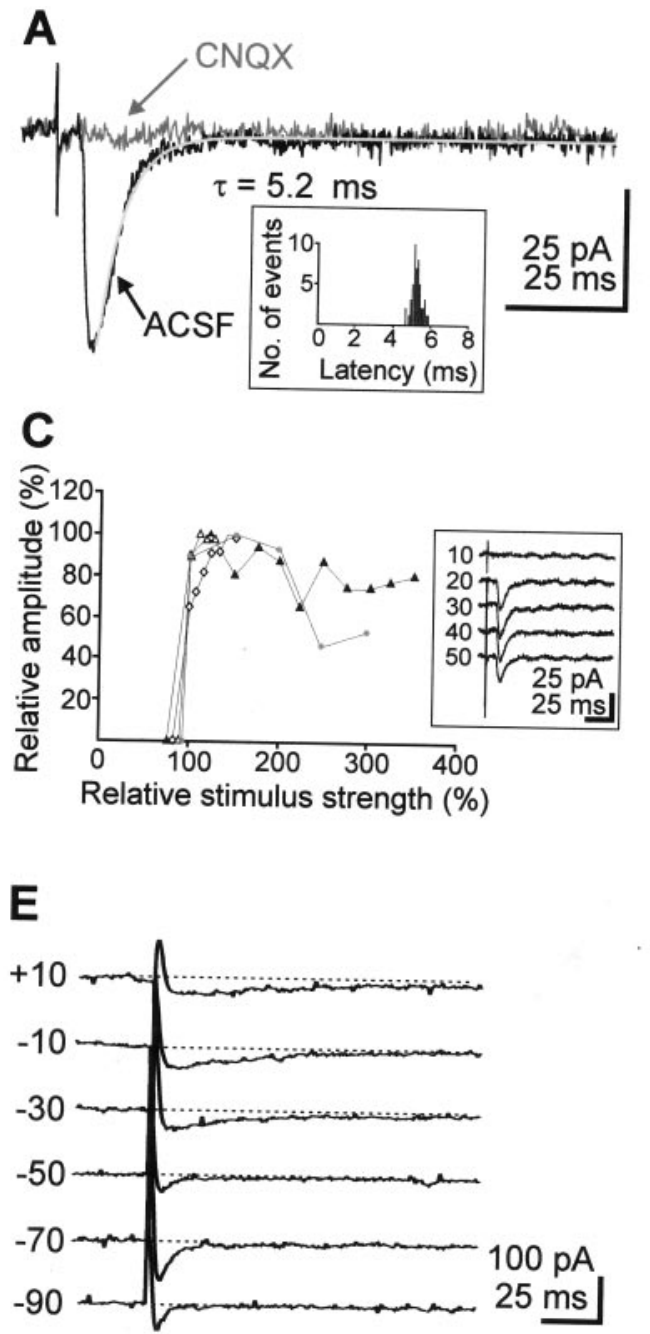

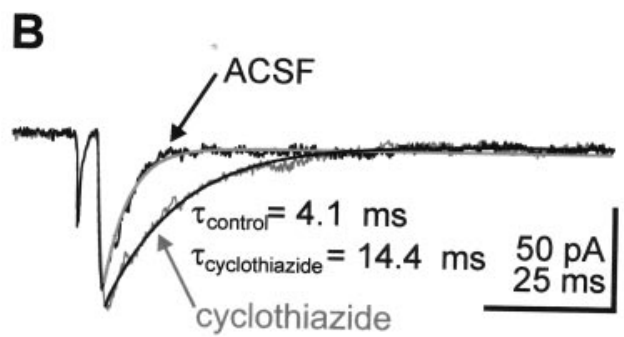

D
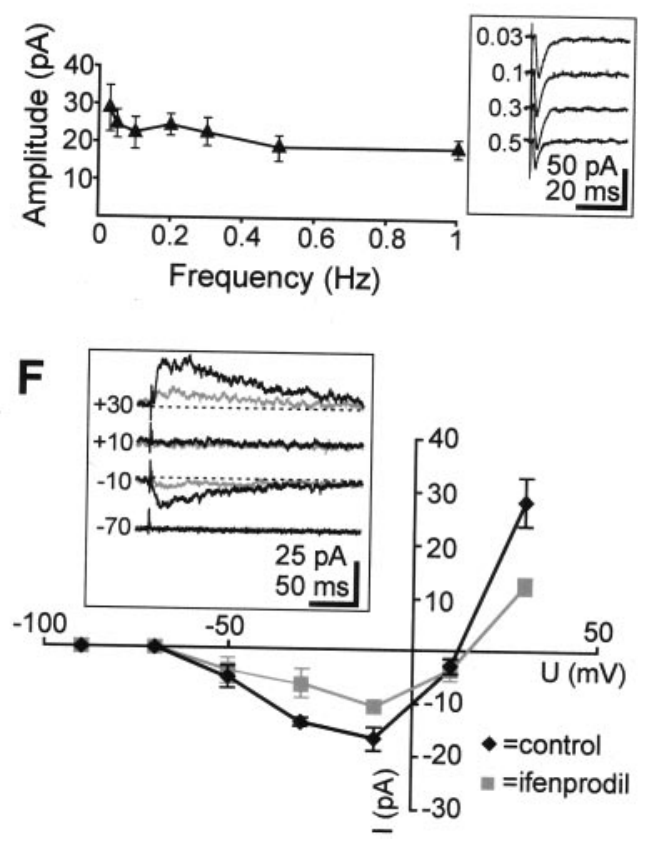

Figure 3. TA-PSCs. A, TA-PSCs recorded in a P3 SPn at a holding potential of $-70 \mathrm{mV}$ under control conditions in ACSF and after bath application of 10 $\mu \mathrm{M}$ CNQX. The PSC decay could be fitted by a monoexponential function (gray line). Inset, Unimodal latency distribution of 50 TA-PSCs recorded from one SPn. $B$, TA-PSCs recorded in a P3 SPn in ACSF and in $100 \mu \mathrm{M}$ cyclothiazide, causing a pronounced prolongation of the response. $C$, Relationship between relative TA stimulation intensity and relative response amplitude of TA-PSCs obtained from four cells. TA-PSC amplitudes and stimulus intensities are normalized to the maximal amplitude and lowest suprathreshold stimulus intensity, respectively. Inset, TA-PSCs recorded in a P3 neuron at stimulus intensities ranging from 10 to $50 \mathrm{~V}$. Stimuli were delivered at $0.03 \mathrm{~Hz}$. D, Relationship between TA stimulation frequency and response amplitude of TA-PSCs obtained from seven SPn. Inset, TA-PSCs recorded in a P3 SPn at different stimulation frequencies. E, TA-PSCs recorded in a P3 SPn at different holding potentials with a QX314-containing electrode solution. Note changes in the kinetics of the TA-PSCs. $F$, Current-voltage relationship of the TA-PSCs recorded from five SPn under control conditions $(10 \mu \mathrm{M}$ CNQX and $100 \mu \mathrm{M}$ gabazine, diamonds) and after application of $3 \mu \mathrm{M}$ ifenprodil (squares). Inset, TA-PSCs recorded in a P1 SPn under control conditions (black traces) and in the presence of ifenprodil (gray traces). Note the reduction of the TAPSCs in ifenprodil. All data are expressed as mean \pm SEM. be best fitted with a monoexponential function (mean decay time constant, $5.4 \pm 0.7 \mathrm{msec} ; n=40$ cells) (Fig. $3 A$ ). This fast kinetic represents a typical feature of AMPA/kainate receptor-mediated PSCs (Trussell et al., 1988; Colquhoun et al., 1992), and similar kinetics have been reported previously for AMPA receptormediated spontaneous PSCs recorded in SPn (Hanganu et al., 2001). Bath application of $10 \mu \mathrm{M}$ CNQX ( $n=8$ cells) blocked the TA-PSCs (Fig. 3A), supporting the assumption that these responses were mediated by activation of AMPA/kainate receptors. This CNQX effect was partially reversible in five SPn. To discriminate between AMPA and kainate receptors, we investigated in six cells the modulation of TA-PSC by cyclothiazide, a drug known to slow the desensitization of AMPA but not of kainate receptors (Partin et al., 1993). Bath application of $100 \mu \mathrm{M}$ cyclothiazide caused a significant $(t$ test; $p<0.05)$ and reversible prolongation in the decay time constants of the TA-PSCs to $339 \pm 107 \%$ of the control value (Fig. $3 B$ ). Furthermore, the TA-PSCs were completely blocked in five of five cells by $80 \mu \mathrm{M}$ GYKI 52466, a selective AMPA receptor antagonist (Paternain et al., 1995). These results indicate that at a holding potential of $-70 \mathrm{mV}$, TA-PSCs are mediated by AMPA receptors.

TA-PSCs were not elicited until a critical threshold of stimulus intensity (varying between 20 and $85 \mathrm{~V}$ ) was reached and a further increase of stimulus strength did not significantly modify their amplitude or shape (Fig. 3C). Therefore, the SPn respond to stimulation in an all-or-none manner, depending on whether TA fire. Antidromic action potentials could never be observed in SPn in response to TA stimulation, even at maximal intensities. These data may indicate that the axonal pathway of the SPn corticothalamic projection differs from the thalamocortical projection. Increasing the frequency of TA stimulation from 0.03 to $1 \mathrm{~Hz}(n=$ 7 cells) did not significantly affect the amplitude of the recorded PSCs (Fig. 3D) but induced in five of seven cells an increase in the failure rate from 8.5 to $28.6 \%$. However, failures of presynaptic transmitter release cannot be unambiguously distinguished from failures of the stimulus to trigger an action potential in the TA (Debanne et al., 1996). To assess the influence of dendritic filtering on the kinetic of the TA-PSCs, we examined the relationship between rise time and decay time constants and between amplitude and decay time constants (Burgard and Hablitz, 1993). Regression analyses $(n=40$ cells) revealed a lack of correlation between these parameters ( $r=0.15$ and 0.09 , respectively), suggesting that dendritic filtering did not profoundly influence the kinetics of the TA-PSCs.

Analysis of the current-voltage relationship of the TA-PSCs indicate that NMDA receptors may also contribute to the thalamocortical inputs onto SPn. At membrane potentials positive to $-50 \mathrm{mV}$, an additional slow component could be identified in 5 
of 11 SPn on TA stimulation (Fig. $3 E, F$ ). This CNQX-insensitive component was blocked by the specific NMDA receptor antagonist CPP, indicating that NMDA receptors with a "classical" $\mathrm{Mg}^{2+}$ block are implicated in the mediation of TA-PSCs. At +10 $\mathrm{mV}$, the pharmacologically isolated NMDA receptor-mediated component of TA-PSCs showed a mean decay-time constant of $68.7 \pm 7.7 \mathrm{msec}(n=4$ cells $)$. The remaining six cells showed PSCs with a linear current-voltage relationship that were completely abolished by CNQX even at depolarized membrane potentials, indicating that they were exclusively mediated by AMPA receptors.

To assess the presence of the NMDA receptor $2 \mathrm{~B}$ (NR2B) subunit in the composition of the NMDA receptors mediating the slow component of the TA-PSCs, ifenprodil, a selective antagonist of NMDA receptors containing the NR2B subunit (Williams, 1993; Williams et al., 1993), was used. Bath application of $3 \mu \mathrm{M}$ ifenprodil significantly $(t$ test; $p<0.01)$ reduced the amplitude from $28.2 \pm 4.7$ to $12.5 \pm 1.5 \mathrm{pA}$ and the decay time constants from $143.8 \pm 23$ to $93.7 \pm 16 \mathrm{msec}$ of the NMDA receptormediated component of TA-PSCs $(n=5$ cells, measured at +30 $\mathrm{mV}$ ) (Fig. $3 F$ ). These results indicate that the NR2B subunit responsible for a strong $\mathrm{Mg}^{2+}$ block is incorporated in the NMDA receptors mediating the TA-PSCs.

TA stimulation did not elicit any GABAergic postsynaptic response in SPn. Even when the chloride concentration in the patch electrode was increased to $136 \mathrm{~mm}$, which causes a shift in the chloride equilibrium potential to $0 \mathrm{mV}$, the amplitude and the kinetics of the TA-PSCs (amplitude, $40.9 \pm 8 \mathrm{pA}$; rise time, $2.5 \pm$ $0.2 \mathrm{msec}$; decay time constant, $7.9 \pm 2 \mathrm{msec}$; and latency, $4.9 \pm 0.5$ msec; $n=11$ cells) were not significantly different from those measured with gluconate-based intracellular solution. Gabazine $(100 \mu \mathrm{M})$, a potent $\mathrm{GABA}_{\mathrm{A}}$ receptor antagonist (Wermuth and Bizière, 1986), had no effect on six of six SPn when a gluconatebased intracellular solution was used and on five of five cells when a high-chloride intracellular solution was used, indicating that stimulation of the thalamocortical afferents did not activate any $\mathrm{GABA}_{\mathrm{A}}$ receptors on SPn.

\section{PSCs evoked by stimulation in the CP}

Electrical stimulation of the CP including layers V and VI elicited in 59 of 82 investigated SPn a PSC with unimodal latency distribution peaking at $5.2 \pm 0.4 \mathrm{msec}(n=59$ cells $)$ and with fast rise time and decay time constants $(2.4 \pm 1.1$ and $5.2 \pm 0.4 \mathrm{msec} ; n=$ 59 cells) (Fig. $4 A$ ). According to these results, the initial PSCs (black dot) elicited by $\mathrm{CP}$ stimulation are most likely to be monosynaptic (CP-monoPSCs). The mean amplitude of the CP-monoPSCs was $34.9 \pm 3.4 \mathrm{pA}(n=59$ cells). This initial CPmonoPSC was followed in 23 of 59 cells by a long-lasting $(60-450$ msec) multiphasic PSC (Fig. 4A). These PSCs are likely to be of polysynaptic origin (CP-polyPSCs). Ten additional SPn exhibited $\mathrm{CP}$-polyPSCs not preceded by a CP-monoPSC. The CPpolyPSCs showed variable maximal amplitudes ranging from 10 to $100 \mathrm{pA}$ (mean, $38.8 \pm 3.7 \mathrm{pA} ; n=33$ cells). The remaining 13 cells showed no response to electrical stimulation. In 7 of 82 cells, maximal stimulation intensities elicited an antidromic action potential, indicating that these SPn possess an ascending axonal projection into the CP. Both CP-monoPSCs ( $n=8$ cells) and CP-polyPSCs ( $n=4$ cells) were completely blocked by $1 \mu \mathrm{M}$ TTX. At $-70 \mathrm{mV}$, the CP-monoPSCs were abolished by $10 \mu \mathrm{M}$ CNQX ( $n=8$ cells) (Fig. $4 B$ ), whereas the NMDA receptor antagonist CPP $(20 \mu \mathrm{M})$ had no significant effect on the amplitude or the kinetics of the monosynaptic responses ( $n=11$ cells) (Fig.
$4 C)$. Because CYZ $(100 \mu \mathrm{M})$ significantly ( $t$ test; $p<0.001)$ increased the decay time constants of the CP-monoPSCs to $337 \pm$ $34 \%$ ( $n=7$ cells) of the control values (Fig. $4 D$ ), and GYKI $52466(80 \mu \mathrm{M})$ completely blocked these responses $(n=5$ cells $)$, we conclude that at $-70 \mathrm{mV}$, the CP-monoPSCs are mediated by AMPA receptors.

The CP-polyPSCs were blocked by $20 \mu \mathrm{M}$ CPP ( $n=6$ cells) (Fig. $4 C$ ), indicating that NMDA receptors are critically involved in the generation of this polysynaptic activity. CNQX $(10 \mu \mathrm{M})$ significantly ( $t$ test; $p<0.05)$ reduced the peak amplitudes of the CP-polyPSCs by $40.8 \pm 13.9 \%$ ( $n=5$ cells) (Fig. $4 B)$. In a bathing solution containing CNQX and CPP ( $n=6$ cells), no synaptic responses were observed.

In contrast to the TA-PSCs, the CP-monoPSCs and particularly the CP-polyPSCs showed pronounced sensitivity to stimulus frequencies of $>0.03 \mathrm{~Hz}$ (Fig. $4 E$ ). Whereas the CP-monoPSCs gradually decreased in their maximal amplitudes at frequencies between 0.03 and $1 \mathrm{~Hz}$, the CP-polyPSCs were already blocked at $>0.03 \mathrm{~Hz}$. When 10 stimuli were applied at a constant frequency of $0.03 \mathrm{~Hz}$, the CP-polyPSCs gradually diminished ( $n=6$ cells), whereas the CP-monoPSCs were relatively stable $(n=7$ cells) (Fig. 4E, inset). Similar results have been reported previously for the immature rat cortex (Kriegstein et al., 1987; Luhmann and Prince, 1990). The lack of a positive correlation between rise time and decay time constants $(r=0.17 ; n=59$ cells $)$ and between amplitude and decay time constants $(r=0.38 ; n=59$ cells $)$ of the CP-monoPSCs indicates that dendritic filtering did not profoundly influence the kinetics of CP-monoPSCs.

In 8 of $10 \mathrm{SPn}$ tested, membrane depolarization to potentials positive to $-50 \mathrm{mV}$ uncovered an additional monosynaptic component, which was CNQX-insensitive and blocked by CPP (Fig. $4 G, H)$. At $+10 \mathrm{mV}$, this NMDA receptor-mediated component of the CP-monoPSCs revealed a mean decay time constant of $125.5 \pm 10.5 \mathrm{msec}(n=6$ cells $)$. The remaining two SPn showed PSCs with linear current-voltage dependence, which were mediated exclusively by AMPA receptors.

The presence of the NR2B subunit in the composition of the NMDA receptors was tested in six SPn. Ifenprodil significantly $(t$ test; $p<0.05)$ reduced the amplitude from $20.2 \pm 3.3$ to $9.2 \pm 1.9$ $\mathrm{pA}$ and the decay time constants from $168.6 \pm 25$ to $72.4 \pm 6.2$ msec of the NMDA receptor-mediated component of CPmonoPSCs $(n=6$ cells, measured at $+30 \mathrm{mV})$ (Fig. $4 H$ ), indicating that the NR2B subunit is incorporated in the NMDA receptors mediating the $\mathrm{CP}$-monoPSCs.

To reveal possible $\mathrm{GABA}_{\mathrm{A}}$ receptor-mediated synaptic inputs arising from the $\mathrm{CP}$ including layers $\mathrm{V}$ and $\mathrm{VI}$, we investigated in seven cells the effects of $100 \mu \mathrm{M}$ gabazine on CP-monoPSCs and CP-polyPSCs. Using patch electrodes with a high chloride concentration $(136 \mathrm{~mm})$, neither the amplitude nor the kinetics of the CP-monoPSCs was affected by gabazine ( $n=7$ cells) (Fig. $4 F)$. However, gabazine significantly $(t$ test; $p<0.01)$ reduced the maximal amplitudes of the CP-polyPSCs by $63 \%(n=5$ cells $)$, suggesting a contribution of $\mathrm{GABA}_{\mathrm{A}}$ receptors to the polysynaptic activity elicited by $\mathrm{CP}$ stimulation.

\section{PSCs evoked by stimulation in the subplate}

Electrical stimulation of the subplate elicited in 34 of 43 investigated SPn a monosynaptic PSC, which in 29 SPn consisted of a dual-component PSC and in the remaining 5 SPn consisted of a single-component PSC. The dual-component PSCs (Fig. 5A) showed a unimodal latency distribution with a peak at $3.9 \pm 0.2$ msec, an average amplitude of $35.8 \pm 3.4 \mathrm{pA}$, and a rise time of 


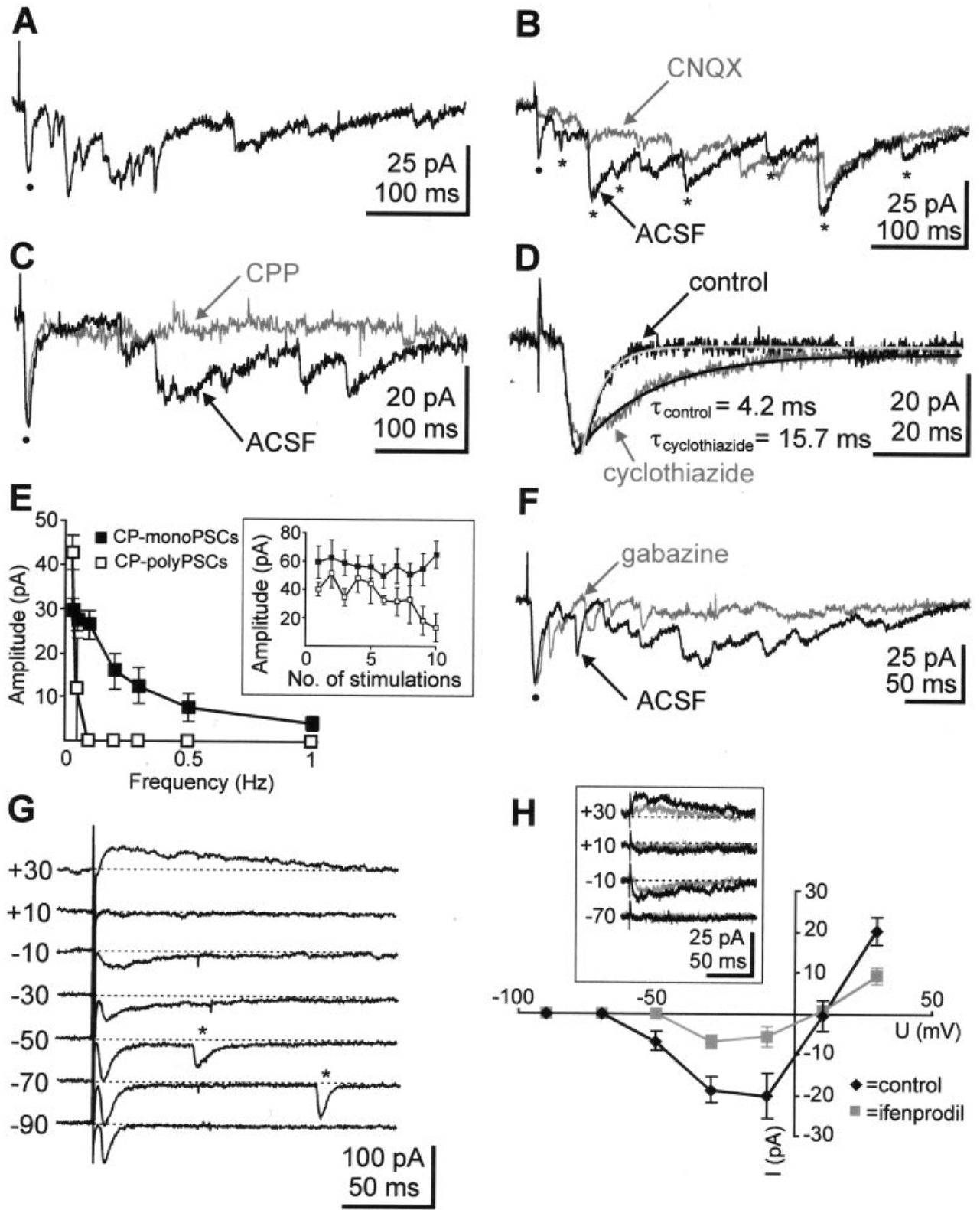

Figure 4. PSCs elicited by electrical stimulation of the cortical plate including layers $\mathrm{V}$ and VI (CP-PSCs). $A$, CP-monoPSC (black dot) and CP-polyPSC responses recorded in a P2 SPn at $-70 \mathrm{mV}$ to electrical stimulation of the cortical plate including layers V and VI. B, CP-PSCs recorded in a $\mathrm{P} 0$ neuron under control conditions and in $10 \mu \mathrm{M}$ CNQX. Note blockade of initial CPmonoPSC (black dot) and reduced amplitudes of CP-polyPSCs (asterisks) in CNQX. $C$, Blockade of CP-polyPSCs by 20 $\mu \mathrm{M} C \mathrm{PP}$ in a $\mathrm{P} 3$ neuron. $D, \mathrm{CP}$-monoPSC recorded in a P3 neuron in $20 \mu \mathrm{M} \mathrm{CPP}$ (control) and after addition of $100 \mu \mathrm{M}$ cyclothiazide. Note prolongation of the CP-monoPSC. E, Relationship between stimulation frequency and amplitude of CP-monoPSCs ( $n=11$ cells $)$ and CPpolyPSCs $(n=2$ cells). Inset, Average response amplitude of CP-monoPSCs ( $n=7$ cells) and CP-polyPSCs $(n=6$ cells) to 10 consecutive stimulations at $0.03 \mathrm{~Hz} . F$, Effect of $100 \mu \mathrm{M}$ gabazine on $C P-P S C s$ recorded in a $\mathrm{P} 3$ neuron. $G, \mathrm{CP}$ monoPSCs recorded in a $\mathrm{P} 1 \mathrm{SPn}$ at different holding potentials with QX-314containing electrode solution. Note changes in the decay kinetics. Asterisks mark spontaneous PSCs. H, Currentvoltage relationship of CP-monoPSCs recorded from six SPn under control conditions $(10 \mu \mathrm{M} C N Q X$ and $100 \mu \mathrm{M}$ gabazine, diamonds) and after addition of $3 \mu \mathrm{M}$ ifenprodil (squares). Inset, CP-monoPSCs recorded in a P3 SPn under control conditions (black traces) and in the presence of ifenprodil (gray traces). Note the reduction of the CP-monoPSCs in ifenprodil.
$2.9 \pm 0.2 \mathrm{msec}$, and their decay could be best fitted by a biexponential function (mean decay time constants, $5.5 \pm 0.7$ and $92.5 \pm$ $15.7 \mathrm{msec} ; n=29$ cells). These data most likely indicate a monosynaptic origin of the PSCs (SP-monoPSCs). In addition, at high stimulation intensities, five SPn revealed polysynaptic responses (SP-polyPSCs) similar to those determined for CPpolyPSCs (latency, $52.8 \pm 18 \mathrm{msec}$; amplitude, $39.4 \pm 8 \mathrm{pA}$; duration, 245-312 msec). These SP-polyPSCs were also critically dependent on NMDA receptors, because they were completely abolished in the presence of $20 \mu \mathrm{M} \mathrm{CPP} \mathrm{(} n=2$ cells).

The dual-component SP-monoPSCs were characterized in more detail by bath application of AMPA/kainate and NMDA receptor antagonists. Application of $20 \mu \mathrm{M}$ CPP abolished in all 21 investigated SPn the slow decaying component of the SPmonoPSC (Fig. 5B, CPP trace). The remaining response revealed an average onset latency of $3.7 \pm 0.2 \mathrm{msec}$, a mean amplitude of $41.8 \pm 5.4 \mathrm{pA}$, and fast rise time and decay time constants of $2.3 \pm 0.1$ and $5.8 \pm 1 \mathrm{msec}(n=21$ cells $)$, respectively. This component was blocked by TTX $(n=4$ cells $)$ and CNQX $(n=11$ cells), indicating that action potential-dependent synaptic transmission and postsynaptic AMPA/kainate receptors are required for this response. Because in four of four cells cyclothiazide (100 $\mu \mathrm{M})$ caused a significant $(t$ test; $p<0.01)$ prolongation in the decay time constant to $290 \pm 33 \%$ of the control (Fig. $5 C$ ), and GYKI $52466(80 \mu \mathrm{M})$ blocked the response in five of five SPn, the fast component of the SP-monoPSCs is most likely mediated by AMPA receptors. Application of $10 \mu \mathrm{M}$ CNQX abolished in all seven investigated cells the fast-decaying component of the SPmonoPSCs (Fig. 5D, CNQX trace). The remaining response revealed an onset latency of $4.9 \pm 0.4 \mathrm{msec}$, an amplitude of $14.6 \pm$ $3.2 \mathrm{pA}$, and significantly ( $t$ test; $p<0.01$ ) longer rise time and decay time constants $(4.7 \pm 0.5$ and $69.5 \pm 9.5 \mathrm{msec} ; n=7$ cells $)$ compared with the AMPA receptor-mediated fast component (Fig. $5 B$ ). This slow SP-monoPSCs component was blocked by 1 $\mu \mathrm{M}$ TTX ( $n=4$ cells) and $20 \mu \mathrm{M}$ CPP $(n=3$ cells $)$, indicating that it requires action potential-dependent synaptic transmission and is mediated by NMDA receptors. Bath application of ifenprodil had no significant effect on the amplitude or decay time 

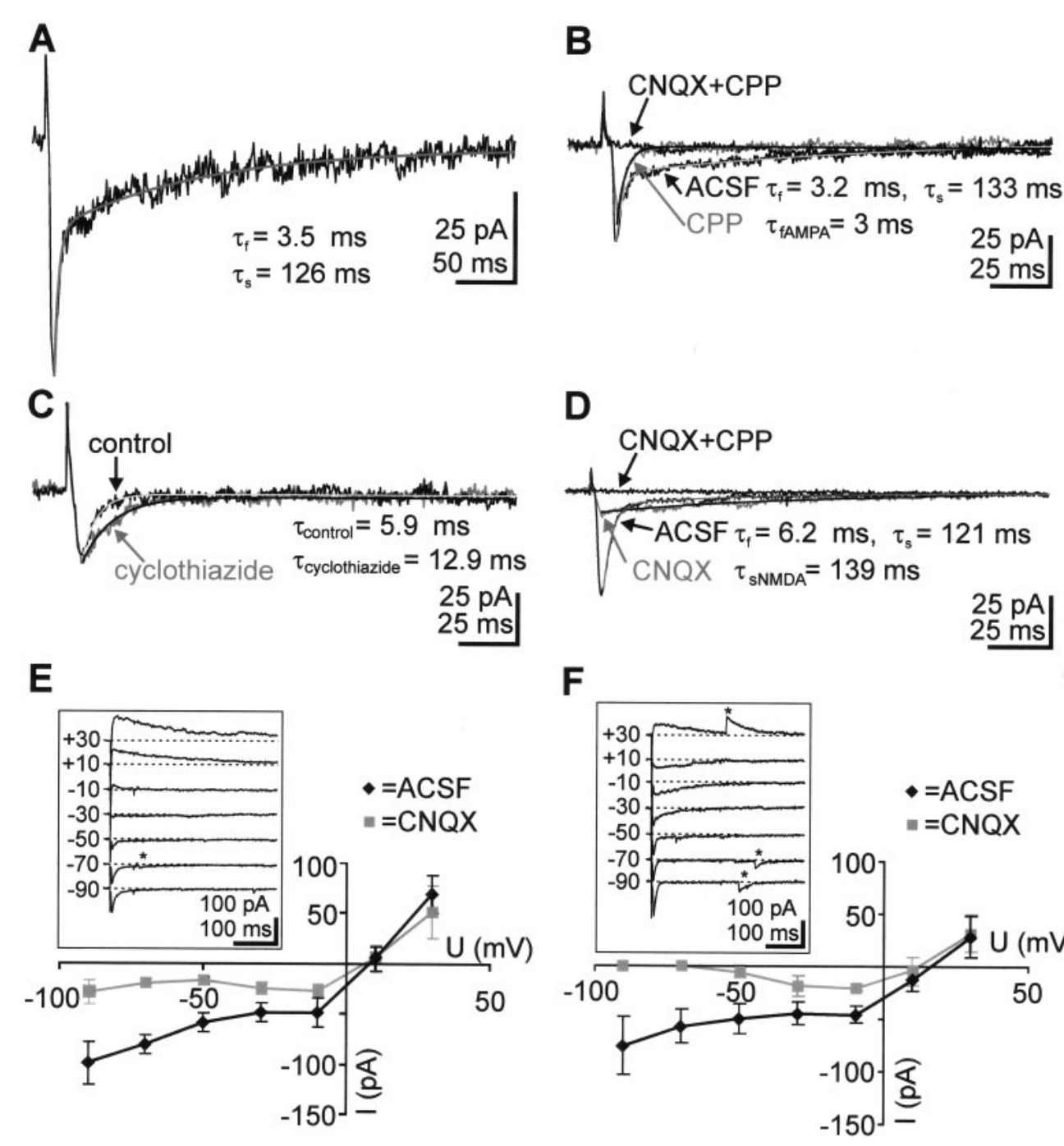

Figure 5. PSCs elicited by electrical stimulation of the subplate. $A$, Monosynaptic dual-component PSC recorded in a P2 SPn at $-70 \mathrm{mV}$. The SP-monoPSC was fitted with a biexponential function corresponding to the fast- and slowdecaying components. $B$, Pharmacological isolation of the fast component by application of $20 \mu \mathrm{M} \mathrm{CPP}$. The CPPinsensitive component could be fitted with a monoexponential function and was blocked by addition of $10 \mu \mathrm{M}$ CNQX. $C$, In CPP-containing bathing solution, application of $100 \mu \mathrm{M}$ cyclothiazide caused a prolongation of the fast component SP-monoPSC. $D$, Pharmacological isolation of the slow component of the SP-monoPSC by bath application of $10 \mu \mathrm{M}$ CNQX. The CNQX-insensitive component could be fitted with a monoexponential function and was blocked by addition of $20 \mu \mathrm{M}$ CPP. $E$, Current-voltage relationship of dual-component SPmonoPSCs recorded from five SPn under control conditions (diamonds) and after application of $10 \mu \mathrm{M} \mathrm{CNQX} \mathrm{(squares).}$ Inset, Dual-component SP-monoPSCs recorded in a P1 SPn at different holding potentials. Note the presence of the NMDA receptor-mediated component at membrane potentials negative to -50 $\mathrm{mV} . F$, Current-voltage relationship of single-component PSCs from three SPn recorded under control conditions (diamonds) and after addition of $10 \mu \mathrm{M}$ CNQX (squares). Inset, SP-monoPSCs recorded in a P1 SPn. Asterisks in $E$ and $F$ mark spontaneous PSCs.
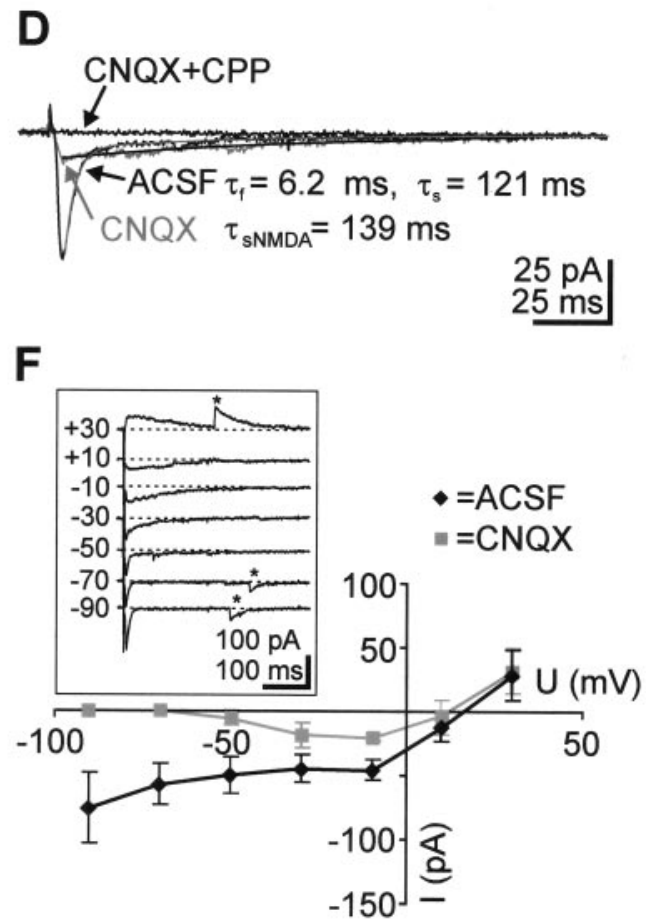

constants of the slow NMDA receptor-mediated component of the dual-component SP-monoPSCs ( $n=5$ cells), indicating that the NR2B subunit is not present in the NMDA receptors at these synapses. Instead, the NR2C subunit may allow the activation of NMDA receptors at membrane potentials negative to $-50 \mathrm{mV}$ because of low $\mathrm{Mg}^{2+}$ sensitivity. On membrane depolarization, the NMDA receptor-mediated component revealed a complex current-voltage relationship and at $+10 \mathrm{mV}$ showed a mean decay time constant of $110.7 \pm 36 \mathrm{msec}(n=5$ cells) (Fig. $5 E)$.

Electrical stimulation of the subplate at frequencies $>0.03 \mathrm{~Hz}$ caused a gradual decrease in the amplitude of the AMPA receptor-mediated component $(n=5$ cells $)$ and at $>0.2 \mathrm{~Hz}$ a blockade of the NMDA receptor-mediated component $(n=3$ cells). Because no correlation between rise time and decay time constants and between amplitude and decay time constants for the AMPA receptor-mediated component $(r=0.02$ and $0.11 ; n=$ 21 cells) and the NMDA receptor-mediated component $(r=0.3$ and $0.04 ; n=7$ cells) could be detected, dendritic filtering did not profoundly influence the kinetics of the fast and slow components of the SP-monoPSCs.

The single-component PSCs showed an unimodal latency distribution peaking at $5.6 \pm 0.8 \mathrm{msec}$, an average amplitude of $28.1 \pm 6.4 \mathrm{pA}$, and a rise time of $2.9 \pm 0.6 \mathrm{msec}$, and their decay could be best fitted by a monoexponential function (mean decay time constant, $4.7 \pm 0.5 \mathrm{msec} ; n=5$ cells $)$. Because the singlecomponent PSCs were completely abolished by $10 \mu \mathrm{M}$ CNQX ( $n=5$ cells) as well as by $80 \mu \mathrm{M}$ GYKI 52466 ( $n=5$ cells), it is mostly likely that at $-70 \mathrm{mV}$, they are mediated by AMPA receptors. Analysis of the current-voltage relationship in three of seven SPn recorded with QX-314-containing electrodes revealed an additional CNQX-insensitive component at membrane potentials positive to $-50 \mathrm{mV}$ (Fig. $5 F$ ). At $+10 \mathrm{mV}$, this component showed a mean decay time constant of $90.5 \pm 9.5 \mathrm{msec}(n=3$ cells) and was blocked by CPP. The remaining four SPn showed single-component PSCs with linear current-voltage dependence that were mediated exclusively by AMPA receptors. The singlecomponent PSCs revealed properties similar to those of the CP-monoPSCs and were elicited most likely by activation of axonal projections arising from layers $\mathrm{V}$ and VI and traversing the subplate.

The contribution of $\mathrm{GABA}_{\mathrm{A}}$ receptors to SP-monoPSCs was studied with increased chloride concentration in the patch electrode and CNQX and CPP in the bathing solution. Under this condition, 13 of 19 investigated SPn revealed a PSC, which was blocked by $1 \mu \mathrm{M}$ TTX ( $n=4$ cells $)$ and by $100 \mu \mathrm{M}$ gabazine $(n=$ 9 cells) (Fig. 6A). These $\mathrm{GABA}_{\mathrm{A}}$ receptor-mediated responses showed large amplitudes $(51.5 \pm 8.3 \mathrm{pA})$, long rise times $(4.5 \pm$ $0.6 \mathrm{msec})$ and decay time constants $(67.6 \pm 11.3 \mathrm{msec})$, and a 


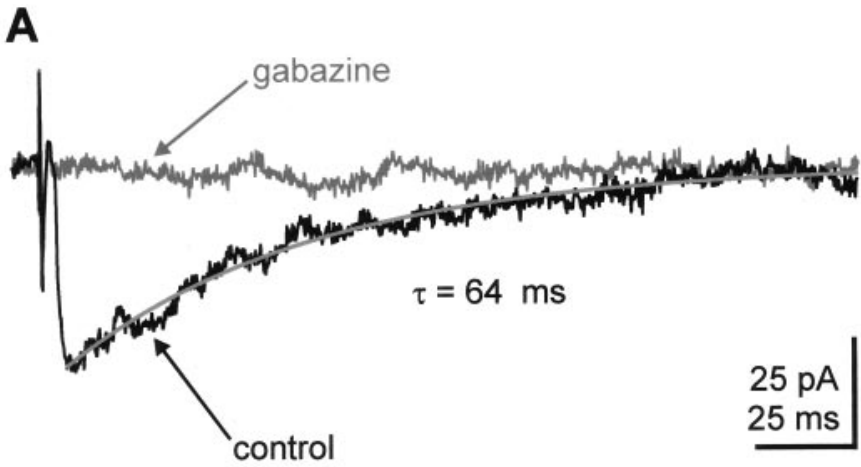

B
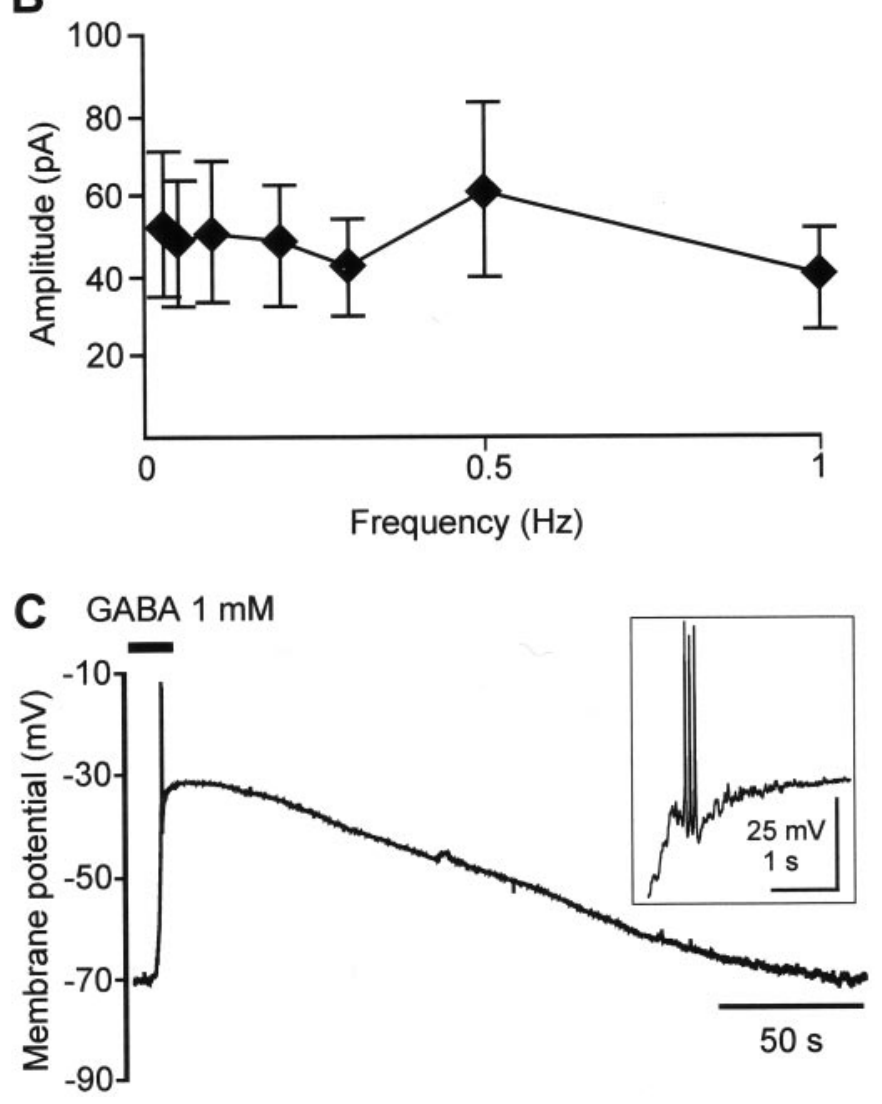

Figure 6. $A, \mathrm{GABA}_{\mathrm{A}}$ receptor-mediated PSC recorded in a P2 SPn after electrical stimulation of the subplate. The recording electrode contained $136 \mathrm{~mm}$ chloride, and holding potential was $-70 \mathrm{mV}$. A control response was recorded in a bathing solution containing $10 \mu \mathrm{M} \mathrm{CNQX}$ and $20 \mu \mathrm{M}$ $\mathrm{CPP}$ to block glutamatergic synaptic transmission. The PSC shows a long decay time constant and was blocked by $100 \mu \mathrm{M}$ gabazine. $B$, Averaged response amplitudes of $\mathrm{GABA}_{\mathrm{A}}$ receptor-mediated PSCs as function of stimulation frequency ( $n=4$ cells). $C$, Depolarizing response to bathapplied GABA recorded in current-clamp mode in a P1 SPn. GABA was applied for $15 \mathrm{sec}$. Note GABA-evoked action potentials, which are displayed at a larger scale in the inset.

unimodal latency distribution with a peak at $4.3 \pm 0.4 \mathrm{msec}(n=$ 13 cells), suggesting a monosynaptic origin. According to the lack of correlation between amplitude and decay time constants $(r=$ $0.2 ; n=13$ cells) and between rise time and decay time constants ( $r=0.4 ; n=13$ cells) dendritic filtering did not profoundly influence the kinetics of the $\mathrm{GABA}_{\mathrm{A}}$ receptor-mediated SPmonoPSCs, suggesting that the slow kinetics of the responses are predominantly determined by the subunit composition of the
$\mathrm{GABA}_{\mathrm{A}}$ receptor during early development (Laurie et al., 1992; Hollrigel and Soltesz, 1997). In contrast to the glutamatergic SP-monoPSCs, increasing stimulation frequencies affected neither the kinetics nor the amplitudes of the $\mathrm{GABA}_{\mathrm{A}}$-mediated SP-monoPSCs ( $n=4$ cells) (Fig. $6 B$ ), indicating stable GABAergic connections between $\mathrm{SPn}$.

\section{Depolarizing action of GABA in SPn}

$\mathrm{GABA}_{\mathrm{A}}$ receptor activation was reported to depolarize immature cortical neurons (Luhmann and Prince, 1991) (for review, see Cherubini et al., 1991; Owens et al., 1996). To study the effects of GABA (1 mM) without altering the intracellular chloride concentration, gramicidin-perforated patch recordings (Kyrozis and Reichling, 1995) were performed on $11 \mathrm{SPn}$. At $-70 \mathrm{mV}$, bath application of GABA for 10-30 sec caused a membrane depolarization to $-40 \pm 3.4 \mathrm{mV}(n=11$ cells $)$ and evoked action potentials in 5 of 11 cells (Fig. $6 C$ ). In all four tested SPn, this GABA effect was abolished by $100 \mu \mathrm{M}$ gabazine. In six cells, the perforated patch recordings were converted to whole-cell recordings, allowing the precise morphological identification of SPn. Taken together, these data demonstrate that GABA depolarizes SPn and evokes or facilitates the firing of action potentials.

\section{DISCUSSION}

The present in vitro electrophysiological study on SPn in neonatal rat somatosensory cortex demonstrates for the first time that SPn receive a distinct synaptic input from cortical and subcortical sources mediated by AMPA, NMDA, and $\mathrm{GABA}_{\mathrm{A}}$ receptors. Monosynaptic inputs arising from the thalamus and the cortical plate are mediated by AMPA receptors and "classical" NMDA receptors, which because of the presence of the NR2B subunit are activated at depolarized membrane potentials. In contrast, monosynaptic inputs from neighboring subplate neurons are mediated by AMPA receptors, classical NMDA receptors, NMDA receptors activated at $-70 \mathrm{mV}$, and $\mathrm{GABA}_{\mathrm{A}}$ receptors mediating a depolarizing action. Beside these monosynaptic inputs, SPn also receive on electrical stimulation of the cortical plate or subplate a polysynaptic input mediated by glutamatergic and $\mathrm{GABA}_{\mathrm{A}}$ receptors. Our data indicate that SPn are integrated in a functional synaptic circuit consisting of the thalamocortical afferents, the cortical plate, including layers V and VI, and the subplate (Fig. 7).

\section{Thalamocortical inputs}

Our observations on the thalamocortical input onto SPn in newborn rat somatosensory cortex are in good agreement with previous observations by Friauf et al. (1990) and Friauf and Shatz (1991) in fetal cat visual cortex. The short-onset latency, the all-or-none character, and the unimodal latency distribution of the PSCs strongly argue for a monosynaptic input. Our observation that the thalamocortical input onto SPn is mediated by AMPA and classical NMDA receptors is in good agreement with previous observations by Agmon and O'Dowd (1992). Further support comes from immunohistochemical studies demonstrating intense NMDA receptor 1 immunoreactivity in SPn (Catalano et al., 1997) and high levels of the AMPA receptor-assembling subunits glutamate receptors 1 and 2/3 (Herrmann, 1996; Furuta and Martin, 1999), whereas the density of kainate receptors remains relatively low (Smith and Thompson, 1999). Our observations on the reliability of the postsynaptic responses to higher stimulus frequencies indicate a mature function of the thalamocortical synapse onto SPn, as it has also been documented by Herrmann et al. (1994) in their ultrastructural analyses. The 


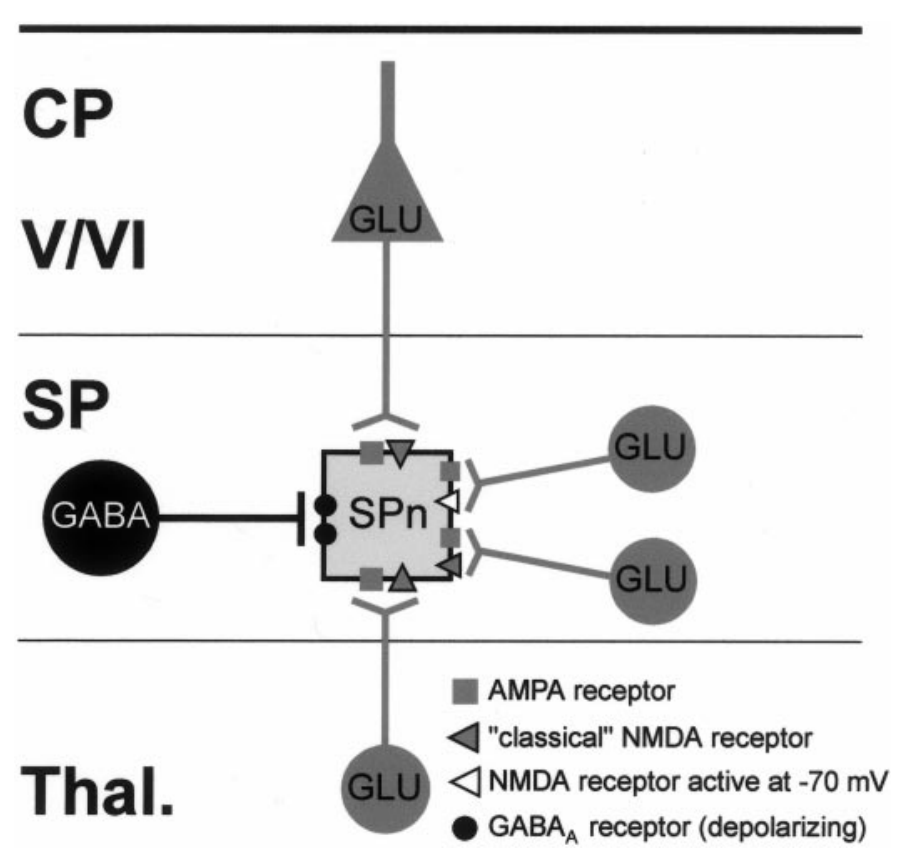

Figure 7. Schematic diagram illustrating the distribution of postsynaptic receptors on an SPn for monosynaptic inputs arising from the thalamus (Thal.) and the CP, including layers V and VI, and within the SP. Note that only synaptic inputs from other SPn can lead to activation of depolarizing $\mathrm{GABA}_{\mathrm{A}}$ receptors and NMDA receptors at negative membrane potentials.

NMDA receptor-mediated PSCs revealed a classical voltagesensitive block by $\mathrm{Mg}^{2+}$ and were reduced by ifenprodil, suggesting that the NMDA receptor at the thalamocortical synapse includes the NR2B subunit (for review, see Feldmeyer and CullCandy, 1996; Cull-Candy et al., 2001).

The lack of any antidromic activity in neonatal rat SPn may indicate that the corticothalamic axons follow a different trajectory as the thalamocortical afferents. In the developing cortex of rodents, a spatial separation of these two axonal projections has been documented (De Carlos and O'Leary, 1992; Agmon et al., 1993; Bicknese et al., 1994) and in the hamster both projection systems are separated through much of the internal capsule (Miller et al., 1993). Therefore, it is most likely that corticothalamic axons are not well preserved under our experimental conditions.

\section{Monosynaptic interactions between cortical plate and subplate}

Previous morphological studies in kitten and ferret visual cortex have demonstrated axonal projections from layer IV spiny neurons (Callaway and Katz, 1992) and layer VI pyramidal cells (Callaway and Lieber, 1996) to the underlying subplate (Shering and Lowenstein, 1994). Consistent with these findings, our data in neonatal rat cortex indicate that layer V and VI neurons form functional synapses with SPn. These monosynaptic connections are fragile and mediated by AMPA and NMDA receptors. The presence of the NR2B subunit may contribute to the classical voltage dependence of the NMDA receptor-mediated synaptic inputs. Because electrical stimulation of layers V and VI elicited antidromic spikes in SPn, our data are also in accordance with previous anatomical studies documenting axonal projections from SPn to the cortical plate (Assal and Innocenti, 1993; Galuske and Singer, 1996; Finney et al., 1998; Clancy et al., 2001). Functional connections between SPn and cortical plate neurons have been demonstrated previously by Friauf and Shatz (1991) in visual cortical slices of fetal cats using current-source density analyses, and immunohistochemical studies by Finney et al. (1998) in ferrets indicate that approximately one-half of cortically projecting SPn are glutamatergic.

\section{Synaptic interactions within the subplate}

Electrical stimulation of the subplate elicited monosynaptic PSCs mediated by AMPA, NMDA, and $\mathrm{GABA}_{\mathrm{A}}$ receptors, suggesting that SPn are interconnected via a dense synaptic network using these three ionotropic receptors. High levels of AMPA and NMDA receptors are transiently expressed in the subplate (Catalano et al., 1997; Furuta and Martin, 1999; Smith and Thompson, 1999), and long-range tangential axonal collaterals arising from inverted pyramidal cells (Assal and Innocenti, 1993; Galuske and Singer, 1996) and other SPn may form the anatomical framework to generate glutamatergic interactions within the subplate. Our data indicate that most of these glutamatergic synapses contain NMDA receptors, which are activated at negative membrane potentials, and AMPA receptors. NMDA receptor-mediated synaptic responses with a relatively weak voltage dependence of magnesium blockade have been reported previously in neonatal rat hippocampus and neocortex (Burgard and Hablitz, 1994; Kirson et al., 1999). Because we observed a substantial NMDA component with a slow decay time constant at membrane potentials negative to $-50 \mathrm{mV}$, which was not blocked by ifenprodil, NMDA receptors containing preferentially the NR1/NR2C subunit combination may be expressed at these synapses (Feldmeyer and Cull-Candy, 1996). However, the presence of NR1-1a (exon5-lacking) subunits with slow deactivation rates, triheteromeric NMDA receptors, or extrasynaptic receptors cannot be excluded (for review, see Cull-Candy et al., 2001). SPn also revealed monosynaptic glutamatergic PSCs mediated by NMDA receptors with classical voltage dependence, indicating that SPn express at least two variations in NMDA receptor subunit combinations, as has been described for other cell types. It may well be that NMDA receptors with different subunit compositions function within a single neuron in a synapse-selective manner (Ito et al., 1997).

In agreement with earlier studies in the hippocampus (Ben-Ari et al., 1989) and neocortex (Luhmann and Prince, 1991; Yuste and Katz, 1991; LoTurco et al., 1995; Owens et al., 1996), our perforated patch recordings from $\mathrm{SPn}$ indicate that $\mathrm{GABA}_{\mathrm{A}}$ receptor activation has a depolarizing effect. Therefore, $\mathrm{SPn}$ are easily excited by network activity involving GABA $_{\mathrm{A}}$, AMPA, and NMDA receptors. However, the rapid fatigue of AMPA and especially NMDA receptor-mediated PSCs during ongoing activity prevent pathophysiological hyperexcitation of this immature network. Our data indicate that the monosynaptic and polysynaptic components involving $\mathrm{GABA}_{\mathrm{A}}$ receptor activation are generated within the subplate, because we never observed a monosynaptic GABAergic input arising from the cortical plate and layers V and VI or from the thalamus. As suggested by Kostovic and Rakic (1980), synaptic inputs forming symmetrical synapses originate from GABAergic SPn, which form a dense, longdistance axonal network within the subplate (Wahle et al., 1987; Van Eden et al., 1989; Antonini and Shatz, 1990; Meinecke and Rakic, 1992). The restriction of monosynaptic GABAergic PSCs to activation of the subplate also indicates that the electrical stimulation procedure preferentially activates indigenous neuronal elements (for discussion of this issue, see Hirsch, 1995). This assumption is supported by our observation that electrical stim- 
ulation of the cortical plate and layers V and VI elicited monosynaptic glutamatergic PSCs with a different kinetic and voltage dependence compared with those evoked by SP stimulation.

\section{Functional role of the subplate}

Although early events in corticogenesis (e.g., regional specification, neurogenesis, migration, and establishment of crude connections) depend on genetic information and molecular cues (for review, see Levitt et al., 1997; Rubenstein et al., 1999), the refinement of the initial crude connectivity during a later stage of development may require neuronal activity (for review, see Katz and Shatz, 1996; Feller, 1999; Zhang and Poo, 2001). Our data indicate that the subplate integrates and processes synaptic inputs from cortical and subcortical structures in an input-specific manner. Thalamic activity is transmitted to the subplate via reliable AMPA and NMDA receptor-mediated synapses and subsequently processed in the cortical plate. Whereas monosynaptic feedback connections from the cortical plate to the subplate are also AMPA and NMDA receptor-mediated, the subplate itself contains an intrinsic network of long-range axonal connections acting via AMPA, NMDA, and depolarizing $\mathrm{GABA}_{\mathrm{A}}$ synapses (Fig. 7). Voigt et al. (2001) demonstrated recently that a subpopulation of large GABAergic SPn generates synchronous intracellular $\left[\mathrm{Ca}^{2+}\right]$ oscillations, which can be blocked by either glutamate or $\mathrm{GABA}_{\mathrm{A}}$ receptor antagonists. This interconnected network of large GABAergic SPn may synchronize thalamocortical inputs, intracortical activity, and modulatory inputs from subcortical sources to form early cortical ensembles. Furthermore, GABA and glutamate released from SPn may regulate neuronal proliferation in the ventricular zone (VZ) and subventricular zone (SVZ) (LoTurco et al., 1995). Interestingly, both amino acids increase cell proliferation in the VZ by shortening the cell cycle but decrease proliferation in the SVZ (Haydar et al., 2000). SPn are ideal candidates to influence proliferation, because (1) they are located close to the VZ and SVZ; (2) they are immunoreactive for GABA and glutamate; and (3) they can generate long-lasting network activity involving GABAergic and glutamatergic synaptic transmission. As already emphasized by Ghosh and Shatz (1992a), the subplate represents more than a passive "waiting station" for afferent systems but also may play an active role in the maturation of the cortex.

\section{REFERENCES}

Agmon A, O'Dowd DK (1992) NMDA receptor-mediated currents are prominent in the thalamocortical synaptic response before maturation of inhibition. J Neurophysiol 68:345-349.

Agmon A, Yang LT, O'Dowd DK, Jones EG (1993) Organized growth of thalamocortical axons from the deep tier of terminations into layer IV of developing mouse barrel cortex. J Neurosci 13:5365-5382.

Antonini A, Shatz CJ (1990) Relation between putative transmitter phenotypes and connectivity of subplate neurons during cerebral cortical development. Eur J Neurosci 2:744-761.

Assal F, Innocenti GM (1993) Transient intra-areal axons in developing cat visual cortex. Cereb Cortex 3:290-303.

Bayer SA, Altman J (1990) Development of layer I and the subplate in the rat neocortex. Exp Neurol 107:48-62.

Ben-Ari Y, Cherubini E, Corradetti R, Gaiarsa J-L (1989) Giant synaptic potentials in immature rat CA3 hippocampal neurones. J Physiol (Lond) 416:303-325.

Bicknese AR, Sheppard AM, O'Leary DDM, Pearlman AL (1994) Thalamocortical axons extend along a chondroitin sulfate proteoglycanenriched pathway coincident with the neocortical subplate and distinct from the efferent path. J Neurosci 14:3500-3510.

Bolz J, Castellani V (1997) How do wiring molecules specify cortical connections. Cell Tissue Res 290:307-314.

Burgard EC, Hablitz JJ (1993) NMDA receptor-mediated components of miniature excitatory synaptic currents in developing rat neocortex. J Neurophysiol 70:1841-1852.

Burgard EC, Hablitz JJ (1994) Developmental changes in the voltage- dependence of neocortical NMDA responses. Brain Res Dev Brain Res 80:275-278.

Callaway EM, Katz LC (1992) Development of axonal arbors of layer 4 spiny neurons in cat striate cortex. J Neurosci 12:570-582.

Callaway EM, Lieber JL (1996) Development of axonal arbors of layer 6 pyramidal neurons in ferret primary visual cortex. J Comp Neurol 376:295-305.

Catalano SM, Shatz CJ (1998) Activity-dependent cortical target selection by thalamic axons. Science 281:559-562.

Catalano SM, Chang CK, Shatz CJ (1997) Activity-dependent regulation of NMDAR1 immunoreactivity in the developing visual cortex. J Neurosci 17:8376-8390.

Cherubini E, Gaiarsa JL, Ben-Ari Y (1991) GABA: an excitatory transmitter in early postnatal life. Trends Neurosci 14:515-519.

Chun JJM, Shatz CJ (1988) Redistribution of vesicle antigens is correlated with the disappearance of a transient synaptic zone in the developing cerebral cortex. Neuron 1:297-310.

Clancy B, Silva M, Friedlander MJ (2001) Structure and projections of white matter neurons in the postnatal rat visual cortex. J Comp Neurol 434:233-252.

Colquhoun D, Jonas P, Sakmann B (1992) Action of brief pulses of glutamate on AMPA/kainate receptors in patches from different neurones of rat hippocampal slices. J Physiol (Lond) 458:261-287.

Cull-Candy S, Brickley S, Farrant M (2001) NMDA receptor subunits: diversity, development and disease. Curr Opin Neurobiol 11:327-335.

DeAzevedo LC, Hedin-Pereira C, Lent R (1997) Callosal neurons in the cingulate cortical plate and subplate of human fetuses. J Comp Neurol 386:60-70.

Debanne D, Guérineau NC, Gähwiler BH, Thompson SM (1996) Pairedpulse facilitation and depression at unitary synapses in rat hippocampus: quantal fluctuation affects subsequent release. J Physiol (Lond) 491:163-176.

De Carlos JA, O'Leary DDM (1992) Growth and targeting of subplate axons and establishment of major cortical pathways. J Neurosci 12:1194-1211.

Feldmeyer D, Cull-Candy S (1996) : Functional consequences of changes in NMDA receptor subunit expression during development. J Neurocytol 25:857-867.

Feller MB (1999) Spontaneous correlated activity in developing neural circuits. Neuron 22:653-656.

Finney EM, Stone JR, Shatz CJ (1998) Major glutamatergic projection from subplate into visual cortex during development. J Comp Neurol 398:105-118.

Friauf E, Shatz CJ (1991) Changing patterns of synaptic input to subplate and cortical plate during development of visual cortex. J Neurophysiol 66:2059-2071.

Friauf E, McConnell SK, Shatz CJ (1990) Functional synaptic circuits in the subplate during fetal and early postnatal development of cat visual cortex. J Neurosci 10:2601-2613.

Furuta A, Martin LJ (1999) Laminar segregation of the cortical plate during corticogenesis is accompanied by changes in glutamate receptor expression. J Neurobiol 39:67-80.

Galuske RAW, Singer W (1996) The origin and topography of longrange intrinsic projections in cat visual cortex: a developmental study. Cereb Cortex 6:417-430.

Ghosh A, Shatz CJ (1992a) Pathfinding and target selection by developing geniculocortical axons. J Neurosci 12:39-55.

Ghosh A, Shatz CJ (1992b) Involvement of subplate neurons in the formation of ocular dominance columns. Science 255:1441-1443.

Hanganu IL, Kilb W, Luhmann HJ (2001) Spontaneous synaptic activity of subplate neurons in neonatal rat somatosensory cortex. Cereb Cortex 11:400-410.

Haydar TF, Wang F, Schwartz ML, Rakic P (2000) Differential modulation of proliferation in the neocortical ventricular and subventricular zones. J Neurosci 20:5764-5774.

Herrmann K (1996) Differential distribution of AMPA receptors and glutamate during pre- and postnatal development in the visual cortex of ferrets. J Comp Neurol 375:1-17.

Herrmann K, Antonini A, Shatz CJ (1994) Ultrastructural evidence for synaptic interactions between thalamocortical axons and subplate neurons. Eur J Neurosci 6:1729-1742.

Hirsch JA (1995) Synaptic integration in layer IV of the ferret striate cortex. J Physiol (Lond) 483:183-190.

Hollrigel GS, Soltesz I (1997) Slow kinetics of miniature IPSCs during early postnatal development in granule cells of the dentate gyrus. J Neurosci 17:5119-5128.

Huntley GW, De Blas AL, Jones EG (1990) GABA A receptor immunoreactivity in adult and developing monkey sensory-motor cortex. Exp Brain Res 82:519-535.

Ito I, Futai K, Katagiri H, Watanabe M, Sakimura K, Mishina M, Sugiyama H (1997) Synapse-selective impairment of NMDA receptor functions in mice lacking NMDA receptor $\epsilon 1$ or $\epsilon 2$ subunit. J Physiol (Lond) 500:401-408.

Kageyama GH, Robertson RT (1993) Development of geniculocortical 
projections to visual cortex in rat: evidence for early ingrowth and synaptogenesis. J Comp Neurol 335:123-148.

Katz LC, Shatz CJ (1996) Synaptic activity and the construction of cortical circuits. Science 274:1133-1138.

Kirson ED, Schirra C, Konnerth A, Yaari Y (1999) Early postnatal switch in magnesium sensitivity of NMDA receptors in rat CA1 pyramidal cells. J Physiol (Lond) 521:99-111.

Kostovic I, Rakic P (1980) Cytology and time of origin of interstitial neurons in the white matter in infant and adult human and monkey telencephalon. J Neurocytol 9:219-242.

Kriegstein AR, Suppes T, Prince DA (1987) Cellular and synaptic physiology and epileptogenesis of developing rat neocortical neurons in vitro. Brain Res Dev Brain Res 34:161-171.

Kyrozis A, Reichling DB (1995) Perforated-patch recording with gramicidin avoids artifactual changes in intracellular chloride concentration. J Neurosci Methods 57:27-35.

Laurie DJ, Wisden W, Seeburg PH (1992) The distribution of thirteen $\mathrm{GABA}_{\mathrm{A}}$ receptor subunit mRNAs in the rat brain. III. Embryonic and postnatal development. J Neurosci 12:4151-4172.

Levitt P, Barbe MF, Eagleson KL (1997) Patterning and specification of the cerebral cortex. Annu Rev Neurosci 20:1-24.

LoTurco JJ, Owens DF, Heath MJS, Davis MBE, Kriegstein AR (1995) GABA and glutamate depolarize cortical progenitor cells and inhibit DNA synthesis. Neuron 15:1287-1298.

Luhmann HJ, Prince DA (1990) Transient expression of polysynaptic NMDA receptor-mediated activity during neocortical development. Neurosci Lett 111:109-115.

Luhmann HJ, Prince DA (1991) Postnatal maturation of the GABAergic system in rat neocortex. J Neurophysiol 65:247-263.

Luhmann HJ, Reiprich RA, Hanganu IL, Kilb W (2000) Cellular physiology of the neonatal rat cerebral cortex: Intrinsic membrane properties, sodium and calcium currents. J Neurosci Res 62:574-584.

Marty M, Neher E (1995) Tight-seal whole-cell recordings. In: Singlechannel recordings (Sakmann B, Neher E, eds), pp 31-52. New York: Plenum.

Meinecke DL, Rakic P (1992) Expression of GABA and GABA receptors by neurons of the subplate zone in developing primate occipital cortex: evidence for transient local circuits. J Comp Neurol 317:91-101.

Mienville JM, Pesold C (1999) Low resting potential and postnatal upregulation of NMDA receptors may cause Cajal-Retzius cell death. J Neurosci 19:1636-1646.

Miller B, Chou L, Finlay BL (1993) The early development of thalamocortical and corticothalamic projections. J Comp Neurol 335:16-41.

Molnár Z, Adams R, Blakemore C (1998) Mechanisms underlying the early establishment of thalamocortical connections in the rat. J Neurosci 18:5723-5745.

Owens DF, Boyce LH, Davis MBE, Kriegstein AR (1996) : Excitatory GABA response in embryonic and neonatal cortical slices demonstrated by gramicidin perforated-patch recordings and calcium imaging. J Neurosci 16:6414-6423.

Partin KM, Patneau DK, Winters CA, Mayer ML, Buonanno A (1993) Selective modulation of desensitization at AMPA versus kainate receptors by cyclothiazide and concanavalin A. Neuron 11:1069-1082.

Paternain AV, Morales M, Lerma J (1995) Selective antagonism of AMPA receptors unmasks kainate receptor-mediated responses in hippocampal neurons. Neuron 14:185-189.

Rakic P (1977) Prenatal development of the visual system in rhesus monkey. Philos Trans R Soc Lond B Biol Sci 278:245-260.

Rakic P (1988) Specification of cerebral cortical areas. Science 241:170-176.
Rubenstein JLR, Anderson S, Shi LM, Miyashita-Lin E, Bulfone A, Hevner R (1999) Genetic control of cortical regionalization and connectivity. Cereb Cortex 9:524-532.

Schröder R, Luhmann HJ (1997) Morphology, electrophysiology and pathophysiology of supragranular neurons in rat primary somatosensory cortex. Eur J Neurosci 9:163-176.

Shatz CJ, Luskin MB (1986) The relationship between the geniculocortical afferents and their cortical target cells during development of the cat's primary visual cortex. J Neurosci 6:3655-3668.

Shering AF, Lowenstein PR (1994) Neocortex provides direct synaptic input to interstitial neurons of the intermediate zone of kittens and white matter of cats: a light and electron microscopic study. J Comp Neurol 347:433-443.

Smith AL, Thompson ID (1999) Spatiotemporal patterning of glutamate receptors in developing ferret striate cortex. Eur J Neurosci 11:923-934.

Staiger JF, Kötter R, Zilles K, Luhmann HJ (1999) Connectivity in the somatosensory cortex of the adolescent rat: an in vitro biocytin study. Anat Embryol (Berl) 199:357-365.

Trussell LO, Thio LL, Zorumski CF, Fischbach GD (1988) Rapid desensitization of glutamate receptors in vertebrate central neurons. Proc Natl Acad Sci USA 85:2834-2838.

Valverde F, Facal Valverde MV, Santacana M, Heredia M (1989) Development and differentiation of early generated cells of sublayer $\mathrm{V} \mathrm{Ib}$ in the somatosensory cortex of the rat: a correlated Golgi and autoradiographic study. J Comp Neurol 290:118-140.

Van Eden CG, Mrzljak L, Voorn P, Uylings HBM (1989) Prenatal development of GABA-ergic neurons in the neocortex of the rat. J Comp Neurol 289:213-227.

Voigt T, Opitz T, de Lima AD (2001) Synchronous oscillatory activity in immature cortical network is driven by GABAergic preplate neurons. J Neurosci 21:8895-8905.

Wahle P, Meyer G (1987) Morphology and quantitative changes of transient NPY-ir neuronal populations during early postnatal development of the cat visual cortex. J Comp Neurol 261:165-192.

Wahle P, Meyer G, Wu JY, Albus K (1987) Morphology and axon terminal pattern of glutamate decarboxylase-immunoreactive cell types in the white matter of the cat occipital cortex during early postnatal development. Brain Res 433:53-61.

Wahle P, Lübke J, Naegele JR (1994) Inverted pyramidal neurons and interneurons in cat cortical subplate zone are labeled by monoclonal antibody SP1. Eur J Neurosci 6:1167-1178.

Wermuth CG, Bizière K (1986) Pyridazinyl-GABA derivates: a new class of synthetic GABA-A antagonists. Trends Pharmacol Sci 7:421-424.

Williams K (1993) Ifenprodil discriminates subtypes of the $N$-methyl-Daspartate receptor: selectivity and mechanisms at recombinant heteromeric receptors. Mol Pharmacol 44:851-859.

Williams K, Russell SL, Shen YM, Molinoff PB (1993) Developmental switch in the expression of NMDA receptors occurs in vivo and in vitro. Neuron 10:267-278.

Yuste R, Katz LC (1991) Control of postsynaptic $\mathrm{Ca}^{2+}$ influx in developing neocortex by excitatory and inhibitory neurotransmitters. Neuron 6:333-344.

Zhang LI, Poo MM (2001) Electrical activity and development of neural circuits. Nat Neurosci [Suppl] 4:1207-1214.

Zhou C, Qiu YH, Pereira FA, Crair MC, Tsai SY, Tsai MJ (1999) The nuclear orphan receptor COUP-TFI is required for differentiation of subplate neurons and guidance of thalamocortical axons. Neuron 24: 847-859. 